\title{
Ethnobotanical Importance of Some Highly Medicinal plants of District Muzaffarabad, Pakistan with special reference to the Species of the Genus Viburnum
}

\author{
Zahid Iqbal Awan ${ }^{1 *}$, Habib-ur-Rehman ${ }^{1}$, Ashfaq Ahmed Awan², Fiaz Aziz \\ Minhas ${ }^{1}$ and Mohammad Nasir Khan ${ }^{2}$. \\ ${ }^{1}$ (Department of Chemistry, University of Azad Jammu and Kashmir, Muzaffarabad 13100, Pakistan). \\ ${ }^{2}$ (Department of Botany, University of Azad Jammu and Kashmir, Muzaffarabad 13100, Pakistan).
}

\begin{abstract}
An ethnobotanical exploration was carried out in Muzaffarabad and its adjoining areas including Jhelum Valley of the District Muzaffarabad during 2010-2011. All the plants with the ethnobotanical importance were identified and segregated separately. The region is entirely mountainous, having sub-tropical to dry temperate climate with distinct seasonal variations. This study mainly focused on the information regarding traditional uses of plants over the years by local inhabitants. The informations were then confirmed by Hakims and the old people of the areas. During the survey informations were collected from various sites, i.e. Noon Bagla, Rahim Kot, Danna Kachilee, Kot Terhala, Sanwarrian, Chikar, Chikothi, Kathiee, Qazi Nag, Rashian, Daokhun, Mojee, Lamnian, Nardaggian, Pandu, Hatian Balla, Ghahi Dopatta, Chinnari, Rabanee, Bani Hafiz, Domel, Hattian Dopatta, Khanssian, Nandi Ka Sar, Sing Paharee,Nari Bela, Khalla Butt and Leepa. The plants were used medicinally and for other purposes. The investigations resulted that usually one plant or a mixture of two or more plant is used. The unplanned exploitation had resulted in the loss of medicinally important plant species. It was concluded that afforestation programme followed by proper protection is need of time.
\end{abstract}

Keywords- District Muzaffarabad, Ethnobotanical, Jhelum Valley, Local Community, Viburnum.

\section{Introduction}

Jhelum Valley is situated in District Muzaffarabad. It is confined to right and left bank of river Jhelum oozes from Chashma Varinag coming from Sirinagar. Jhelum Valley is located between $34^{\circ} 30$ latitude and $77^{\circ}$ 98 longitude. It is bounded in the South by Kaffer Khun, in the North by Leepa Valley, in the East by Qazi Nag and West by Domel. It has rugged topography comprising mainly steep slops and gullies, where limestone rocks are basically common. The climate is variable between lower and higher altitude. January is the coldest month of the year. Usually winter is longer than summer and is very cold. June is the hottest month but generally the summer is pleasant. The average maximum and minimum temperature of the year is 25 through $0^{\circ} \mathrm{C}$ respectively. Main stream in the valley is Qazi Nag, which joins at Chinari with the river Jhelum.

Jhelum valley and its adjoining areas are rich in medicinal plants yet neglected. This area demands extensive ethnobotanical and floristic survey. The botanist are mainly interested in obtaining such data from the tribes and recording it for further work. Such efforts have been made by Schultes $(1960,1962)$ and Altschul $(1967,1968,1970,1975$ and 1977) [1, 2, 3-7]. Who have made significant contribution for the ethnobotanical studies and reported economic and medicinal uses of plants which were not known earlier to scientific world.

Historically, the knowledge of medicinal plants was restricted to a few specialized herbal healers in rural communities; thus, much of their use was seen as being primarily of local interest (Arnold and Perez 2001) [8]. For the past two decades, medicinal plants have been increasingly recognized for their role in improving the economic status of rural people who sell these plants in markets worldwide (Phillips and Meilleur 1998; Ojha 2000; Ticktin et al 2002) [9-11]. Threatened medicinal plant species have become the focus of world attention because they represent an extending flora which need protection and conservation and because of their role as an essential commodity for health care (Gustafsson 2002; Kala 2002) [12, 13]. The Himalayas span eight countries (i.e. Afghanistan, Bhutan, Bangla desh, China, Myanmar, Nepal, Pakistan and India) are reputed to be a rich storehouse of medicinal plant species.

The population of Jhelum valley is entirely rural; few people are engaged in local jobs, trade and employment is higher in cities of the country. Principal tribes in the valley are Gujjar, Kashmiree, Syed, Timbree and Awan. The languages they speak are Gojri, Pahari and Kashmiree.

Since the time of early Neanderthal man, plants have been used for healing purposes, even as modes of medicine changed throughout the centuries, plants continued to be the mainstay of country medicine as method and ideas on plant healing were passed down from family to family and within communities. Thus tribes, 
villages, towns, sometime entire countries tended to have similar styles in healing. Many simple people knowing nothing about botany, chemistry or pharmacology have ears better tuned to catch remedies. Rustic lore often hides for years, the treasure that nature secreted in the roots, stem, bark, juice, flowers, fruit and seeds of plants. Some of them are now worldwide remedies.

Laporatti and Lattazi (1994) studied 27 medicinal plants from Makran [14]. Godman and Ghaffoor (1992) conducted ethnobotanical study in Baluchistan of Southwest Pakistan [15].

Plants have played a vital role in human civilization. The Indian subcontinent represents one of the most important region all over the world, from economic and ethnobotanical point of view work has been done among the workers, Harshburger (1896) and others are important [16].

In Pakistan only a few papers have been published in the field of ethnobotany. Khan (1994) described the past and present status of natural thorn forest in Panjab [17]. Hijazi (1984) reported the most common shrub of Margalla Hills National Park [18]. Akbar (1988) analysis the vegetation of Quid-Azam University campus established seven communities [19]. The area has been included in the sub-tropical shrub forest by previous workers (Champion et al 1965) [20]. Hocking $(1958,1962)$ wrote a series of papers on medicinal plants of Pakistan and included some information on Baluchistan [21,22].

Shinwari and Malik (1989) concluded a field study of plant utilization of Northern Baluchistan [23]. Shahzad and Qureshi (2001) discussed common ethnobotanical uses of plants in Jatlan area, District Mirpur [24]. Shinwari (1996) reported the present status of ethnobotany in Pakistan [25]. Hamid et al (1998) reported the medicinal plants of Pakistan [26].

For the area like Jhelum valley no information about the plants used in medicine and other purposes by local inhabitants is available. Inspite of this all the above mentioned studies mainly emphasis on medicinal importance of all or some of the known plants found in a particular area and no such information is available which can represent the medicinal knowledge of species of a particular genus. As for as genus Viburnum is concerned no doubt it has wide range of medicinal uses but very few information is available. The objective of this study was to explore the treasure and also to enlist and confirm the species that are used for different purposes, nationally trade important.

\section{Materials and Methods}

Medicinal plants continue to be extensively used as a major source of drugs for treatment of many ailments. Pakistan especially Azad Kashmir being rich in indigenous herbal resources offer great scope for ethnobotanical studies.

Plants were collected from Jhelum valley and its adjoining areas of District Muzaffarabad, pressed in presser paper and were dried carefully. Data regarding different ethnobotanical aspects were collected from local people of the area. The collected plants were identified with the help of literature (Nasir and Ali, 19701987) [27]. Further identifications were done by comparing the collected plants with reference plants in Herbarium of the Department of Botany, University of Azad Jammu and Kashmir, Muzaffarabad.

The specimen was collected in flowering and fruiting conditions during the field trips and complete information about their local names, parts of the plants utilized, mode of application, specificity and periodicity of doses were properly recorded and actually gathered with the help of local informants and other elders, traditional medicinal practioners. The study has been carried out during the year 2005-2006 in several localities of District Muzaffarabad. A questionnaire was designed to document traditional knowledge of medicinal and economical plants. Field studies were conducted. The number of people with whom the information was collected varied from 50-60 depending upon availability. Majority of people illiterate and about $15 \%$ of respondent were primary, matric and college education. More than $30 \%$ respondent interviewed were active, cooperative and aged varied from 45-60 years.

The average number of house holds in different villages visited was 52 with a population of about 570600 heads, where people lived with their own way of life, believe and cultural heritage. The number of dependent per family heads was 10 but the average number of children was 6. Majority of the residents (6090\%) depend on farming.

Per capita land holding varied from 0.37 to 1.20 ha, which was not sufficient to fulfill the basic needs. They were doing other jobs in addition to farming. Respondent benefited from natural resources other than firewood like collection of medicinal plants, morel, grazing and grass cutting. They enhanced their income from the sale of non-timber forest products. Majority of the respondent reluctant to tell the exact quantity of medicinal plants and morel extracted in a season. However, some of them (20\%) told that 1-1.5 quintal (fresh wt.) of medicinal plants and morel were collected per family for sale and local uses in a season.

The plant remedies usually employed in common ailments like cough, asthma, dyspepsia, skin diseases, typhoid, malaria, eye-trouble, body pain, cuts and wounds. Thus people saved handsome amount instead of purchasing costly allopathic medicines for the treatment of these diseases. The inhabitants only preferred to visit 
hospital/doctors in serious cases. The information collected on crude drugs items sold by local dealers in the recent years are given in Table-I.

Table-I: $\quad$ Crude Drug Items Sold by Local Dealers in the Recent Year.

\begin{tabular}{llllll} 
S.\# & Scientific name & Local name & $\begin{array}{l}\text { Qty } \\
\text { (tonnes) }\end{array}$ & $\begin{array}{l}\text { Rate/Kg } \\
\text { (Rs.) }\end{array}$ & $\begin{array}{l}\text { Appox. Value of } \\
\text { herbal drugs sold (Rs.) }\end{array}$ \\
\hline 1 & Viola Serpens & Thandi-boot & 2.00 & 175 & 350,000 \\
2 & Paeonia emodi & Mamekh & 4.00 & 50 & 200,000 \\
3 & Berberis Lycem & Kashmal & 1.00 & 100 & 100,000 \\
4 & Valeriana Jatamansi & Mushak bala & 0.50 & 2000 & 100,000 \\
5 & Geranium Wallichiana & Ratan jot & 0.20 & 50 & 10,000 \\
6 & Acorus calamus & Bach & 1.20 & 375 & 450,000 \\
7 & Skimia laureola & Ner & 1.00 & 12 & 12,000 \\
8 & Rhem emodi & Chutial & 0.16 & 50 & 8,000 \\
9 & Zanthoxylum armantum & Timber & 0.20 & 10 & 2,000 \\
10 & Morchela esculanta & Guchi & 0.20 & 600 & $12,000,00$ \\
11 & Veronia anthelmintica & Kali zeri & 0.80 & 20 & 16,000 \\
12 & Zizyphus vulgaris & Unab & 0.60 & 12 & 7,200 \\
\hline
\end{tabular}

Total:

III. Result and Discussion

The paper involves the ethnobotanical enumeration of Viburnum species, their botanical names, local names, locality, family, distribution, description and uses as medicinal herbs. However, during the survey some of the other medicinal plants of the different genus and families have also been explored and recorded.

Viburnum is a genus of about 200 species of shrubs or (in a few species) small trees that were previously included in the family Caprifoliaceae. Genetic tests by Angiosperm Phylogeny Groups showed however, that they are correctly classified in the family Adoxaceae. They are native throughout the temperate and subtropical regions of Northern Hemisphere, with a few species extending into tropical mountain regions in South America, Asia, North America and Malaysia. In Africa, the genus is confined to the Altas Mountains. Its 200 species are known, including the following.

Viburnum acerifolium

Viburnum betulifolium

Viburnum bracteatum

Viburnum burejaeticum

Viburnum carlessi

Viburnum cinnamonifolium

Viburnum corylifolium

Viburnum cylindricum

Viburnum davidii

Viburnum dilatatum

Viburnum ellipticum

Viburnum erubescens

Viburnum foetens

Viburnum furcatum

Viburnum harryanum

Viburnum hirtum

Viburnum ichangense

Viburnum kansuense

Viburnum lantanoides

Viburnum lobophyllum

Viburnum molle

Viburnum mullaha

Viburnum odoratissimum

Viburnum orientale
Viburnum atrocyaneum

Viburnum bitchiuense

Viburnum buddleifolium

Viburnum calvum

Viburnum cassinoides

Viburnum cordifolium

Viburnum cotinifolium

Viburnum dasyanthum

Viburnum dentatum

Viburnum edule

Viburnum erosum

Viburnum farreri

Viburnum foetidum

Viburnum grandiflorum

Viburnum henryi

Viburnum hupehense

Viburnum japonicum

Viburnum lantana

Viburnum lentago

Viburnum macrocephalum

Viburnum mongolicum

Viburnum nudum

Viburnum opulus

Viburnum phlebotrichum 


\author{
Viburnum pilcatum \\ Viburnum refinesquianum \\ Viburnum rhytidophyllum \\ Viburnum rufidulum \\ Viburnum schensianum \\ Viburnum setigernum \\ Viburnum suspensum \\ Viburnum ternatum \\ Viburnum trilobum \\ Viburnum utile \\ Viburnum venosum \\ Viburnum wrightii
}

\author{
Viburnum propinquum \\ Viburnum recognitum \\ Viburnum rigidum \\ Viburnum sargentii \\ Viburnum sempervirens \\ Viburnum sieboldii \\ Viburnum sympodiale \\ Viburnum tinus \\ Viburnum urceolatum \\ Viburnum veitchii \\ Viburnum wilsonii
}

In Pakistan and Azad Kashmir Viburnum is represented by the following six species; two species are reported to be cultivated by Rolan Copper in1914. It is distributed in Himalaya from Sawat eastward to Bhutan, South Tibbet. In Azad Kashmir it is distributed in Peer Chanasi, Shudhan gulli, Jhelum valley at 1500-3000 m.

- Viburnum cotinifolium

- Viburnum mullaha

- Viburnum grandiflorum

- Viburnum cylindricum

- Viburnum opulus

- Viburnum tinus

The leaves are opposite, simple and entire toothed or lobed; cool temperate species are decidous, while most of the warm temperate species are evergreen. Some species are densely hairy on the shoots and leaves with star shaped hairs.

The flowers are produced in corymbs $5-15 \mathrm{~cm}$ across, each flower white to cream or pink, small 3-5 mm across, with five petals, strongly fragrant in dome species. The gynoecium has three connate carpels with the nectary on top of the gynoecium. Some species have a fringe of large, showy sterile flowers round the perimeter of the corymb to act as a pollinator target.

The fruit is spherical, oval or somewhat flattened drupe, red to purple, blue or black and containing a single seed; they are eaten by birds and other wildlife, and some are edible for humans. The leaves are sometime eaten by the larvae of some Lepidoptera species.

Many species of Viburnum become popular as garden or landscape plants because of their showy flowers and barriers and generally good autumn colors.

Information about the plants, which were useful, collected and documented as used by the local people. Medicinal plants are either used singly (mufrad) or in combination with some other plants or plant parts (murrakkab). Natural vegetation of medicinal plants was adversely affected by a number of factors, in the area explored. Vegetation of the area was intensely affected by heavy grazing and fall of trees, unplanned exploitation had resulted in loss of such medicinally important plant species. Some species that were common in the past were rarely found now. It is concluded that local people, hakims and traders collect and use the plants, which are being eradicated and becoming rare. It is suggested that afforestation programme followed by proper protection is the need of time.

The plants of the genus are found to be used in the folk medicine system. It has been employed with benefit in all nervous complaints and debility and used with success in cramps and spasms of all kinds. In convulsions, fits, lockjaw and also in palpitation, heart disease and rheumatism. It is used as remedy for constipation and is highly energetic. The fruit are blood producer and purifier, leaf extract is used as carminative. A drug prepared from the bark which is used for dysmenorrhea and asthma. It prevents the threaded abortion and checks hemorrhage. 
Ethnobotanical Importance of Some Highly Medicinal plants of District Muzaffarabad.

Table-II: Ethnobotanical Status of Some Highly Medicinal Plants of District Muzaffarabad with special reference to Genus Viburnum.

\begin{tabular}{|c|c|c|c|c|c|}
\hline $\begin{array}{l}\text { Sr } \\
\dot{\mathrm{N}} \\
\text { o. }\end{array}$ & Family Name & Botanical Name & Local Name & Status & Ethnobotanical Uses \\
\hline \multirow[t]{2}{*}{1} & Amaranthceae & $\begin{array}{l}\text { Aerva javanica Juss ex } \\
\text { Scult }\end{array}$ & Booh & Herb & $\begin{array}{l}\text { The decoction of the plant is used to } \\
\text { remove swellings. }\end{array}$ \\
\hline & & $\begin{array}{l}\text { Amaranthas viridus } \\
\text { Linn. }\end{array}$ & Ganhar & Herb & $\begin{array}{l}\text { Leaves used as vegetable, roots } \\
\text { laxative, seeds for curing backache. }\end{array}$ \\
\hline 2 & Aceraceae & $\begin{array}{l}\text { Acer caesium wall ex } \\
\text { Brandis }\end{array}$ & Tarkanna/killu & Tree & $\begin{array}{l}\text { Leaves used for fodder, wood used as } \\
\text { fuel and For making furniture. }\end{array}$ \\
\hline 3 & Alliaceae & Allium humile & Pari pyaz & Herb & $\begin{array}{l}\text { Fresh leaves used as vegetable, dried } \\
\text { leaves as flavoring agent, used in } \\
\text { gastric problems. }\end{array}$ \\
\hline \multirow[t]{5}{*}{4} & Asteraceae & $\begin{array}{l}\text { Achillea millefolia } \\
\text { Linn. }\end{array}$ & Sultani booti & Herb & $\begin{array}{l}\text { Stomachache, diuretic, leaves are } \\
\text { chewed in acute toothache, tea made } \\
\text { from roots to treat fever. }\end{array}$ \\
\hline & & Artimisia scoparia $\mathrm{L}$. & Jahoo & Herb & $\begin{array}{l}\text { Powdered root used to treat epilepsy, } \\
\text { tea made to treat sore throat. }\end{array}$ \\
\hline & & $\begin{array}{l}\text { Saussurea costus } \\
\text { (falc.) Lipsch }\end{array}$ & Kuth & Herb & $\begin{array}{l}\text { Dried root is used to treat asthma and } \\
\text { in certain cardiac complaints, dried } \\
\text { roots with sugar are used to treat } \\
\text { backache problem. }\end{array}$ \\
\hline & & $\begin{array}{l}\text { Echinops echinatus } \\
\text { Roxb. }\end{array}$ & Tik & Herb & $\begin{array}{l}\text { The plant is bitter; stomachic, } \\
\text { antipyretic, analgesic, anti- } \\
\text { inflammatory, appetizer; stimulates the } \\
\text { liver. }\end{array}$ \\
\hline & & $\begin{array}{l}\text { Eclipta alba (L.) } \\
\text { Hasskl. }\end{array}$ & Tik & Shurb & $\begin{array}{l}\text { The plant has a bitter sharp dry taste, } \\
\text { tonic, expectorant, antipyretic, } \\
\text { anodyne, and stomachic, useful in } \\
\text { diseases of the spleen, stomatitis, and } \\
\text { hepatitis; cures vertigo. In tattooing } \\
\text { the natives after puncturing the skin } \\
\text { rub the juicy green leaves over the part } \\
\text { which gives the desired indelible color } \\
\text { viz., a deep bluish black. }\end{array}$ \\
\hline 5 & Acanthaceae & $\begin{array}{l}\text { Blepharis sindica } \\
\text { Stocks ex Anders. }\end{array}$ & Assad & Herb & The seeds are used as cure for Otalgia. \\
\hline \multirow[t]{2}{*}{6} & Asclepiadaceae & $\begin{array}{l}\text { Calotropis procera } \mathrm{R} . \\
\mathrm{Br} .\end{array}$ & $\mathrm{Ak}$ & Tree & $\begin{array}{l}\text { The bast fiber obtained from the stem } \\
\text { is used for making ropes and cordage. } \\
\text { The silky coma of seeds is used for } \\
\text { stuffing pillows, making shawls and } \\
\text { handkerchiefs. Leaves are also used as } \\
\text { poultice for sprains. Flowers useful in } \\
\text { cholera. Milky juice (latex) is useful } \\
\text { for toothache. The whole plants are } \\
\text { used for the fencing and fodder for } \\
\text { goats (Capra hircus). }\end{array}$ \\
\hline & & $\begin{array}{l}\text { Oxystelma esculenta } \\
\text { (L. f) R. Br. }\end{array}$ & Dudhi & Shurb & $\begin{array}{l}\text { The fruit is bitter; tonic, expectorant, } \\
\text { anthelmintic; juice is useful in gleets, } \\
\text { gonorrhea, pain in the muscles, cough, } \\
\text { leucoderma; milky sap forms a wash } \\
\text { for ulcers. The natives eat the fruit in } \\
\text { famine. The whole plant is fodder for } \\
\text { goats (Capra hircus) and sheep (Ovis } \\
\text { aries). }\end{array}$ \\
\hline 7 & Arecaceae & $\begin{array}{l}\text { Nannorrhops } \\
\text { ritchieana } \mathrm{H} \text {. Wendl. }\end{array}$ & Pish & Shurb & $\begin{array}{l}\text { The young leaf or cabbage is eaten, } \\
\text { also used in the treatment of diarrhoea } \\
\text { and dysentery. Mats, sandals, ropes, } \\
\text { fans, baskets, and brooms are made } \\
\text { from the leaves. The reddish moss like } \\
\text { wool of the petioles is used as tinder. } \\
\text { The seeds are used into rosaries. }\end{array}$ \\
\hline 8 & Apocynaceae & Nerium oleander L. & Zangi Gul & Herb & Decoction of leaves in paste form is \\
\hline
\end{tabular}




\begin{tabular}{|c|c|c|c|c|c|}
\hline & & & & & $\begin{array}{l}\text { applied externally on the skin to cure } \\
\text { certain skin diseases. The root is bitter } \\
\text { aphrodisiac, tonic, good for chronic } \\
\text { pain in the abdomen and pain in the } \\
\text { joints; very poisonous but an antidote } \\
\text { to snake venom. Flowers are sacred to } \\
\text { Hindu deity Siva and are used by } \\
\text { Hindus in religious ceremonies. } \\
\text { Highly toxic for humans as well as } \\
\text { livestock, camels (Camelo } \\
\text { dromedarium) sometimes eat the } \\
\text { leaves of } \\
\text { the plant but they always prove fatal. }\end{array}$ \\
\hline & & Rhazya stricta Dcne. & Sainwar & Herb & $\begin{array}{l}\text { The infusion of fresh leaves is used in } \\
\text { bath water as cooling agent. The } \\
\text { powdered leaves and fruits are applied } \\
\text { on skin to treat rashes. The extract } \\
\text { from fresh fruits is used in treating } \\
\text { sore eyes. The fruits and leaves are } \\
\text { considered efficacious in cases of boils } \\
\text { and eruption. Also remedy for snake } \\
\text { bite, tooth and eye diseases. The roots } \\
\text { are used as a febrifuge. }\end{array}$ \\
\hline \multirow[t]{3}{*}{9} & Boraginaceae & $\begin{array}{l}\text { Arnebiabenthamii } \\
\text { Wall ex G. Don }\end{array}$ & Gao zaban & Herb & $\begin{array}{l}\text { Roots used in backache, tea made } \\
\text { from roots carminative. }\end{array}$ \\
\hline & & $\begin{array}{l}\text { Cordia gharf (Forssk.) } \\
\text { Ehren. ex Asch. }\end{array}$ & Lyar & Tree & $\begin{array}{l}\text { The decoction of the bark possesses } \\
\text { astringent properties and is used as a } \\
\text { gargle. The wood is used for making } \\
\text { small agricultural implements } \\
\text { (ploughs \& yokes) and household } \\
\text { articles. Ripe fruit (drupe) is eaten. }\end{array}$ \\
\hline & & $\begin{array}{l}\text { Trichodesma indicum } \\
\text { L. }\end{array}$ & Gaozaban & Herb & $\begin{array}{l}\text { The whole plant as poultice is used as } \\
\text { emollient. Leaves are anti-venom used } \\
\text { to cure snakebite. }\end{array}$ \\
\hline 10 & Brassicaceae & $\begin{array}{l}\text { Capsella bursa } \\
\text { pastoris } \mathrm{L} .\end{array}$ & Bun paincha & Herb & $\begin{array}{l}\text { Juice of whole plant used in chest } \\
\text { problems and to stop nose bleeding. }\end{array}$ \\
\hline 11 & Burseraceae & $\begin{array}{l}\text { Commiphora wightii } \\
\text { (Arn.) Bhandari }\end{array}$ & Guggul, Mukul & Herb & $\begin{array}{l}\text { The gum is aphrodisiac, demulcent, } \\
\text { aperients, carminative; useful in } \\
\text { nervous diseases, urinary disorders } \\
\text { and skin diseases. Dry gum resin is } \\
\text { used in religious ceremonies. Hindus } \\
\text { as they believe that fumes of resin } \\
\text { ward off evil spirits. The gum is also } \\
\text { used to cement the broken pottery. }\end{array}$ \\
\hline 12 & Bignoniaceae & $\begin{array}{l}\text { Tecomella undulata } \\
\text { Roxb. }\end{array}$ & Lohiro & Tree & $\begin{array}{l}\text { The wood used for building items } \\
\text { (pillar, beam, rafter) and agricultural } \\
\text { implements (ploughs, yokes, shafts, } \\
\text { beams). The bark of the young } \\
\text { branches of the tree is employed as } \\
\text { remedy in syphilis. It is also used to } \\
\text { cure hepatitis, leucorrhoea and fevers. } \\
\text { Fresh branches lopped as fodder for } \\
\text { goats (Capra hircus) and camels } \\
\text { (Camelus dromedarius). }\end{array}$ \\
\hline 13 & Cannabaceae & Canabis sativa Linn. & Bhang & Herb & $\begin{array}{l}\text { Leaves and flowers used as narcotic, } \\
\text { in combination with tobacco to treat } \\
\text { asthma, fiber from stem is used to } \\
\text { make ropes. Oil is edible and used in } \\
\text { cold season to keep body warm, seed } \\
\text { used as poultry feed to enhance egg } \\
\text { production. }\end{array}$ \\
\hline 14 & Caprifoliaceae & $\begin{array}{l}\text { Viburnum } \\
\text { grandiflorum }\end{array}$ & Ikloo/Guch & Shrub & $\begin{array}{l}\text { Leaves purgative and diuretic, bark } \\
\text { used against malaria; fruit edible, used } \\
\text { for menorrhagia and metorrhagoa, } \\
\text { blood purifier. }\end{array}$ \\
\hline
\end{tabular}


Ethnobotanical Importance of Some Highly Medicinal plants of District Muzaffarabad.

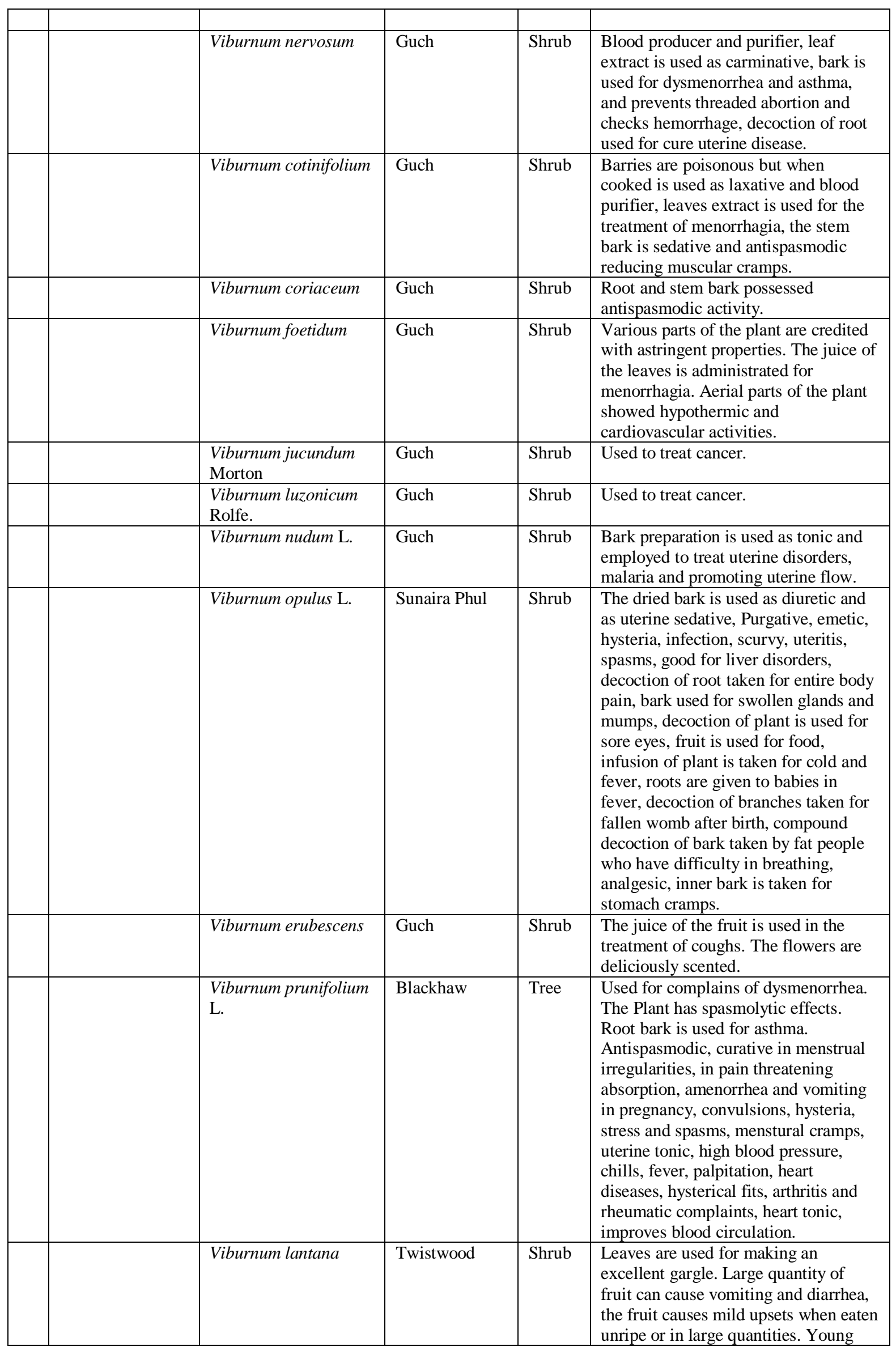


Ethnobotanical Importance of Some Highly Medicinal plants of District Muzaffarabad.

\begin{tabular}{|c|c|c|c|c|c|}
\hline & & & & & $\begin{array}{l}\text { stem can be used as twine, good } \\
\text { indicator of limy soil. Hemolytic and } \\
\text { hypotensive effects. }\end{array}$ \\
\hline & & Viburnum alnifolium & Guch & Shrub & Uterine sedative action. \\
\hline & & Viburnum trilobum & Guch & Shrub & Growth regulations. \\
\hline & & Viburnum awabuki & Guch & Shrub & Antioxidant. \\
\hline & & Viburnum tinus & Guch & Shrub & $\begin{array}{l}\text { Hemolytic and weak Hypotensive } \\
\text { effects. }\end{array}$ \\
\hline \multirow[t]{2}{*}{15} & Chenopodiaceae & $\begin{array}{l}\text { Chenopodium album } \\
\text { Linn. }\end{array}$ & Bathwa & Herb & $\begin{array}{l}\text { Young leaves and branches used as } \\
\text { vegetable. Dried leaves used in pain. }\end{array}$ \\
\hline & & $\begin{array}{l}\text { Sueda fruticosa }(\mathrm{L} .) \\
\text { Forssk. }\end{array}$ & Lanee & Tree & $\begin{array}{l}\text { Khar (crude soda) is prepared from } \\
\text { this plant for washing purpose. The } \\
\text { leaves are applied as poultice in } \\
\text { ophthalmia and used sometimes } \\
\text { infused in water as an emetic. }\end{array}$ \\
\hline 16 & Cupressaceae & $\begin{array}{l}\text { Juniperus communis } \\
\text { Pallas. }\end{array}$ & Bhanthari & Shrub & $\begin{array}{l}\text { Branches used as fuel. Fruit used to } \\
\text { increase mucous secretion and helps in } \\
\text { digestion and relieves gas. }\end{array}$ \\
\hline \multirow[t]{2}{*}{17} & Cuscutaceae & Cuscuta europea & Neela dhari & $\begin{array}{l}\text { Twinn } \\
\text { er }\end{array}$ & $\begin{array}{l}\text { Poultice made from plant used against } \\
\text { insect sting and piles. }\end{array}$ \\
\hline & & Cuscuta reflexa Roxb. & Bepari, Kasus & Tree & $\begin{array}{l}\text { The plant is purgative. The seeds have } \\
\text { a bitter bad taste sedative, } \\
\text { Emmenagogue, diuretic; useful in } \\
\text { diseases of the liver, spleen, quartan } \\
\text { fever, chronic fevers, griping, } \\
\text { hiccoughs. Seeds are bruised they are } \\
\text { used for washing the hair. }\end{array}$ \\
\hline 18 & Cyperaceae & $\begin{array}{l}\text { Cyperus rotundus } \\
\text { Linn. }\end{array}$ & Jabbay gha & Herb & $\begin{array}{l}\text { Leaves used to make rope, root paste } \\
\text { used in wounds and fever. }\end{array}$ \\
\hline 19 & Capparidaceae & $\begin{array}{l}\text { Capparis decidua } \\
\text { (Forssk.) Edgew. }\end{array}$ & Kirrur & Tree & $\begin{array}{l}\text { The bark is used as an analgesic, } \\
\text { diaphoretic, laxative, anthelmintic, } \\
\text { antitussive. The fruit is useful in } \\
\text { cardiac troubles and also used in } \\
\text { pickles. Wood is used for agricultural } \\
\text { implements (ploughs and yokes) and } \\
\text { for making roofs of huts and for } \\
\text { household articles like spoons, } \\
\text { dippers and stirrers. Fodder for goats } \\
\text { (Capra hircus) and camels (Camelus } \\
\text { dromedarius). }\end{array}$ \\
\hline \multirow[t]{2}{*}{20} & Cucurbitaceae & $\begin{array}{l}\text { Citrulus colocynthis } \\
\text { (L.) Schrad. }\end{array}$ & Truh & Tree & $\begin{array}{l}\text { Root is useful in mastitis, arthrititis. } \\
\text { The fruit is bitter pungent cooling, } \\
\text { purgative, anthelmintic antipyretic, } \\
\text { carminative, cures tumors, ascites, } \\
\text { leucoderma, ulcers, asthma, bronchitis, } \\
\text { jaundice, enlargement of spleen, } \\
\text { tuberculosis glands, dyspepsia, } \\
\text { constipation, anemia, laryngitis. Fruit } \\
\text { is administrated to cattle for intestinal } \\
\text { disorders. }\end{array}$ \\
\hline & & $\begin{array}{l}\text { Coccinea grandis }(\mathrm{L} .) \\
\text { Voigt. }\end{array}$ & $\begin{array}{l}\text { Golaru, } \\
\text { Kanduri }\end{array}$ & Tree & $\begin{array}{l}\text { The fresh juice extracted from the } \\
\text { roots and leaves are given in the } \\
\text { treatment of diabetes. The leaves of } \\
\text { this plant are boiled in gingelly oil and } \\
\text { applied externally in ringworm. The } \\
\text { fruit is an aphrodisiac; allays thirst; } \\
\text { useful in biliousness. }\end{array}$ \\
\hline 21 & Convolvulaceae & $\begin{array}{l}\text { Convolvulus arvensis } \\
\mathrm{L} .\end{array}$ & Naro & Shrub & $\begin{array}{l}\text { The roots possess the cathartic } \\
\text { properties. Whole plant used as fodder } \\
\text { for goats (Capra hircus) and sheep } \\
\text { (Ovis aries). }\end{array}$ \\
\hline 22 & Dipsacaeae & $\begin{array}{l}\text { Dipsacus inermis Wall } \\
\text { ex Roxb. }\end{array}$ & Oppalha & Herb & $\begin{array}{l}\text { Leaves used as vegetable, folder and } \\
\text { sexual tonic for females. }\end{array}$ \\
\hline 23 & Euphorbiaceae & $\begin{array}{l}\text { Euphorbia helioscopia } \\
\text { Linn. }\end{array}$ & Dodhal & Herb & $\begin{array}{l}\text { Dried root used to stimulate secretion, } \\
\text { fever, abdominal pain and blood }\end{array}$ \\
\hline
\end{tabular}


Ethnobotanical Importance of Some Highly Medicinal plants of District Muzaffarabad.

\begin{tabular}{|c|c|c|c|c|c|}
\hline & & & & & purifier. \\
\hline \multirow[t]{6}{*}{24} & Fabaceae & $\begin{array}{l}\text { Quercus dilatata } \\
\text { Griffth. }\end{array}$ & Choor & Tree & $\begin{array}{l}\text { Leaves used as fodder for cattle, sour } \\
\text { mouth, seed used to cure sour mouth } \\
\text { and throat. }\end{array}$ \\
\hline & & $\begin{array}{l}\text { Acacia senegal (L.) } \\
\text { Willd. }\end{array}$ & Babur & Tree & $\begin{array}{l}\text { The powdered gum is used to check } \\
\text { severe epistaxis. The wood is used for } \\
\text { making agricultural implements i.e. } \\
\text { ploughs / yokes, huts (pillar) and } \\
\text { household articles also used for fuel by } \\
\text { the tribals. Young branches are lopped } \\
\text { for goats (Capra hircus) and sheep } \\
\text { (Ovis aries) as fodder. }\end{array}$ \\
\hline & & $\begin{array}{l}\text { Albizzia lebbeck (L) } \\
\text { Benth. }\end{array}$ & Sireenh & Tree & $\begin{array}{l}\text { The bark is bitter cooling, anthelmintic } \\
\text { cures leucoderma, itching and piles; } \\
\text { also used by the tribals for tanning } \\
\text { leather which is black to brown color. } \\
\text { The flowers are used as a cooling } \\
\text { medicine and also externally applied } \\
\text { in boils eruption and swellings. The } \\
\text { leaves are useful in ophthalmia and } \\
\text { nyctalopia. The wood has high local } \\
\text { timber value for agricultural } \\
\text { implements, furniture, for huts and } \\
\text { houses (beam and doorframe). }\end{array}$ \\
\hline & & $\begin{array}{l}\text { Alhahi maurorum } \\
\text { Medic. }\end{array}$ & Kas kundero & Shrub & $\begin{array}{l}\text { The extract from fresh leaves is used } \\
\text { as eye-drops to relieve soreness and } \\
\text { redness. The powdered roots are taken } \\
\text { as anti-diabetes. As fodder relished by } \\
\text { camels (Camelus dromedarius) and } \\
\text { goats (Capra hircus). It is also used in } \\
\text { making door screens. }\end{array}$ \\
\hline & & $\begin{array}{l}\text { Crotalaria burhia } \\
\text { Ham. ex. Bth. }\end{array}$ & Sim & Tree & $\begin{array}{l}\text { Bast fiber extracted from the stem by } \\
\text { the tribals used for ropes and cordage. } \\
\text { The tribals make huts (walls, roof) } \\
\text { using dry plants. The branches and } \\
\text { leaves are used as a cooling agent to } \\
\text { alleviate fever. }\end{array}$ \\
\hline & & $\begin{array}{l}\text { Prosopis cineraria } \\
\text { (L.) Druce }\end{array}$ & Kandee & Tree & $\begin{array}{l}\text { The pod is considered astringent. The } \\
\text { bark is used as a remedy for } \\
\text { rheumatism. Women eat the flowers } \\
\text { during pregnancy to safeguard them } \\
\text { against miscarriage. The ashes are } \\
\text { rubbed over the skin to remove hair. } \\
\text { The natives eat mealy pulp contained } \\
\text { in the pod having a sweetish taste, } \\
\text { either raw or cooked as a vegetable. } \\
\text { Hindus worship trees during the } \\
\text { Dussera festival. The wood is used for } \\
\text { making agricultural implements viz., } \\
\text { ploughs, yokes and beams. Branches } \\
\text { lopped as fodder for goats (Capra } \\
\text { hircus). }\end{array}$ \\
\hline 25 & Flacourtiaceae & $\begin{array}{l}\text { Flacourtia indica } \\
\text { (Burm.) Merrill. }\end{array}$ & Bhutankas & Tree & $\begin{array}{l}\text { The fruits are sweet, appetizing and } \\
\text { digestive are useful in jaundice and } \\
\text { enlarged spleen. Seeds are ground to a } \\
\text { powder with turmeric and rubbed all } \\
\text { over the body after parturition, to } \\
\text { prevent rheumatic pains. }\end{array}$ \\
\hline \multirow[t]{2}{*}{26} & Gentianaceae & $\begin{array}{l}\text { Swertia paniculata } \\
\text { Wall. }\end{array}$ & Jabba jarri & Herb & $\begin{array}{l}\text { Whole plant used to diarrhea, malarial } \\
\text { fever and weakness. }\end{array}$ \\
\hline & & $\begin{array}{l}\text { Gentianoides kurroo } \\
\text { Royle }\end{array}$ & Jarri & Herb & Whole plant is used as blood purifier. \\
\hline 27 & Geraniaceae & $\begin{array}{l}\text { Geranum } \\
\text { wallichianum }\end{array}$ & Ratan -jot & Herb & $\begin{array}{l}\text { Burnished root used in hay fever, } \\
\text { diabetic and urinary disease. }\end{array}$ \\
\hline 28 & Hydrocharitaceae & Hyocyamus niger & Ajwain & Herb & Used for narcotics also used in asthma \\
\hline
\end{tabular}


Ethnobotanical Importance of Some Highly Medicinal plants of District Muzaffarabad.

\begin{tabular}{|c|c|c|c|c|c|}
\hline & & & & & and whooping cough. \\
\hline \multirow[t]{3}{*}{29} & Labiateae & $\begin{array}{l}\text { Ajuga bracteosa Wall } \\
\text { ex Benth }\end{array}$ & Maneer & Herb & $\begin{array}{l}\text { Leaves used in stomachache and as } \\
\text { blood Purifier. }\end{array}$ \\
\hline & & Mentha longifolia $\mathrm{L}$. & Poodna & Herb & $\begin{array}{l}\text { Leaf extract used against vomiting and } \\
\text { dysentery. Leaf in dry powdered from } \\
\text { used in asthma and as condiment. }\end{array}$ \\
\hline & & Thymus linearis & Bun Jamain & Herb & $\begin{array}{l}\text { Decoction of leaves and flowers used } \\
\text { against dysentery and in stomach } \\
\text { problems. Tea made from flowers is } \\
\text { carminative. }\end{array}$ \\
\hline 30 & Lorantaceae & Vuscum album $\mathrm{L}$. & Neela & $\begin{array}{l}\text { Parasit } \\
\text { e on } \\
\text { trees }\end{array}$ & $\begin{array}{l}\text { Leave diuretic, fruit used as glue, used } \\
\text { as fodder for goats and sheep. }\end{array}$ \\
\hline 31 & Lamiaceae & Ocimum basilicum $\mathrm{L}$. & Nazbo, Sabajhi & Herb & $\begin{array}{l}\text { The plant is pungent and dry } \\
\text { stomachic, anthelmintic, antipyretic, } \\
\text { improves the taste useful in diseases of } \\
\text { the heart and blood. The juice of the } \\
\text { leaves forms an excellent nostrum for } \\
\text { the cure of ringworm and bruised } \\
\text { leaves for scorpion stings. The flowers } \\
\text { possess stimulant, diuretic and } \\
\text { demulcent properties. The seeds are } \\
\text { mucilaginous and cooling given in } \\
\text { infusion in gonorrhea, diarrhea and } \\
\text { chronic dysentery. A cold infusion is } \\
\text { said to relieve the after pains of } \\
\text { parturition. The powder (dried leaves) } \\
\text { is used in culinary. }\end{array}$ \\
\hline \multirow[t]{2}{*}{32} & Moraceae & Ficus palmate Wall. & Phagwar toot & Tree & $\begin{array}{l}\text { Fruit edible, laxative, wood used as } \\
\text { fuel and milk used to cure warts. }\end{array}$ \\
\hline & & Morus alba $\mathrm{L}$. & Toot & Tree & $\begin{array}{l}\text { Fruit used in fever and sour throat } \\
\text { young branches used in making } \\
\text { baskets, wood used in making } \\
\text { furniture. }\end{array}$ \\
\hline 33 & Morinaceae & $\begin{array}{l}\text { Morina lonicaule Wall } \\
\text { ex D. C. }\end{array}$ & Jer & Herb & $\begin{array}{l}\text { Roots used to treat wounds and kills } \\
\text { worms. }\end{array}$ \\
\hline 34 & Menispermaceae & $\begin{array}{l}\text { Cocculus pendulus } \\
\text { Diels. }\end{array}$ & Zamhar & Herb & $\begin{array}{l}\text { Whole plant is used in the treatment of } \\
\text { intermittent fevers. }\end{array}$ \\
\hline \multirow[t]{2}{*}{35} & Oleaceae & $\begin{array}{l}\text { Jasminum humile } \\
\text { Linn. }\end{array}$ & Chamba & Shrub & $\begin{array}{l}\text { Flowers used in perfumes, roots used } \\
\text { against worms, flower extract used in } \\
\text { eye problems. }\end{array}$ \\
\hline & & $\begin{array}{l}\text { Olea ferruginea } \\
\text { Royle }\end{array}$ & Khau & Tree & $\begin{array}{l}\text { Leaves used in toothache, astringent, } \\
\text { antiseptic, diuretic, anti-periodic, sore } \\
\text { throat. The root is applied for scorpion } \\
\text { sting. Fruit is eaten, anti-diabetic. } \\
\text { Wood is used for making agricultural } \\
\text { tools (ploughs and yokes) also fuel. }\end{array}$ \\
\hline 36 & Orchidaceae & $\begin{array}{l}\text { Habenaria pectinata } \\
\text { D. Don. }\end{array}$ & Nar madi & Herb & $\begin{array}{l}\text { Root used as blood purifier, also used } \\
\text { to increase sexual power in males. }\end{array}$ \\
\hline \multirow[t]{2}{*}{37} & Papilonaceae & Trifolium repens L. & Sinja & Herb & Used as vegetable, as fodder. \\
\hline & & $\begin{array}{l}\text { Indigofera hetranth } \\
\text { Wall ex Brandis. }\end{array}$ & Kanthi & Shrub & $\begin{array}{l}\text { Branches used in making baskets, as } \\
\text { fuel, as making miswak and as fuel. }\end{array}$ \\
\hline \multirow[t]{2}{*}{38} & Pinaceae & Abies pindrow Royle. & Rewar & Tree & $\begin{array}{l}\text { Wood used in furniture, house making } \\
\text { and fuel. }\end{array}$ \\
\hline & & $\begin{array}{l}\text { Pinus wallichiana A. } \\
\text { B. Jakson }\end{array}$ & Biarr & Tree & $\begin{array}{l}\text { Wood used in furniture, shoot used as } \\
\text { fuel, resin used in paints. Fruit edible. }\end{array}$ \\
\hline 39 & Plantaginaceae & $\begin{array}{l}\text { Plantago lanceolata } \\
\text { Linn }\end{array}$ & Chamchi patra & Herb & $\begin{array}{l}\text { Leaves used as vegetable applied on } \\
\text { wound and burns. Seed used against } \\
\text { constipation. }\end{array}$ \\
\hline \multirow[t]{2}{*}{40} & Poaceae & $\begin{array}{l}\text { Saccharum } \\
\text { spontanium Linn. }\end{array}$ & Narri & Herb & $\begin{array}{l}\text { Used as fodder and for making pen } \\
\text { (Qalam). }\end{array}$ \\
\hline & & $\begin{array}{l}\text { Saccharum bengalense } \\
\text { Retz. }\end{array}$ & Sirkee & Tree & $\begin{array}{l}\text { Culms are cooling, aphrodisiac useful } \\
\text { in burning sensations, thirst, } \\
\text { erysipelas, blood troubles urinary }\end{array}$ \\
\hline
\end{tabular}




\begin{tabular}{|c|c|c|c|c|c|}
\hline & & & & & $\begin{array}{l}\text { complaints, eye disease, also used for } \\
\text { hut making, Cheeks (screen), fencing } \\
\text { and pens (Kilks). On the occasion of } \\
\text { Holi and Diwali festivals Hindus } \\
\text { worship the culms bearing } \\
\text { inflorescence (arrows) called Hira } \\
\text { Moti with the belief that the year will } \\
\text { bring prosperity and fortune. Stems } \\
\text { and leaves fiber is obtained by } \\
\text { maceration and beating which is made } \\
\text { in to good serviceable ropes for cots } \\
\text { and cordage. }\end{array}$ \\
\hline & & Cynodon dactylon $\mathrm{L}$. & Chhabbar & Shrub & $\begin{array}{l}\text { The extract of whole plant is useful in } \\
\text { curing diarrhea and opthalmia. The } \\
\text { decoction from roots is used to treat } \\
\text { gonorrhea and other urogenital } \\
\text { ailments. It affords fodder for horses } \\
\text { (Equus caballus) and onagers (Equus } \\
\text { heminous onager). }\end{array}$ \\
\hline & & $\begin{array}{l}\text { Desmostachya } \\
\text { bipinnata (L.) Stapf. }\end{array}$ & Dabh & Herb & $\begin{array}{l}\text { The root is sweet cooling useful in } \\
\text { thirst, asthma, jaundice, biliousness, } \\
\text { diseases of the blood, The plant is } \\
\text { sweet acrid, cooling, oleaginous, } \\
\text { aphrodisiac, diuretic. The culms are } \\
\text { said to posses diuretic and stimulant } \\
\text { properties. Hindus keep the grass at } \\
\text { the time of solar and lunar eclipses in } \\
\text { the belief that edible things will not be } \\
\text { affected by harmful radiation. }\end{array}$ \\
\hline 41 & Podophyllaceae & Podophyllum emodi & Khakhri & Herb & $\begin{array}{l}\text { Fruit edible. Root paste applied on } \\
\text { ulcers, cuts and wounds, used to treat } \\
\text { vaginal warts. Powdered roots used to } \\
\text { increase yield of butter. }\end{array}$ \\
\hline \multirow[t]{3}{*}{42} & Polygonaceae & $\begin{array}{l}\text { Polygonum } \\
\text { amplexicaule }\end{array}$ & Masloon & Herb & $\begin{array}{l}\text { Leaf extract is used to beatify the skin. } \\
\text { Tea made from root against asthma } \\
\text { also fodder for animals. }\end{array}$ \\
\hline & & $\begin{array}{l}\text { Rheum webbiana } \\
\text { Royle }\end{array}$ & Chotyal & Herb & $\begin{array}{l}\text { Roots used in headache and stomach } \\
\text { pain. }\end{array}$ \\
\hline & & $\begin{array}{l}\text { Rumex nepalensis } \\
\text { Linn. }\end{array}$ & Hola & Herb & $\begin{array}{l}\text { Decoction and leaves and roots used in } \\
\text { cuts. }\end{array}$ \\
\hline \multirow[t]{2}{*}{43} & Primulaceae & $\begin{array}{l}\text { Androsece hazarica } \mathrm{R} . \\
\text { r. Stewart. }\end{array}$ & Hazari boti & Herb & $\begin{array}{l}\text { Leaves in combination with sugar and } \\
\text { ghee used in correcting menstrual flow } \\
\text { in females of age group 20-30. }\end{array}$ \\
\hline & & Anagallis arvensis $\mathrm{L}$. & Bili booti. & Herb & $\begin{array}{l}\text { It is used in cerebral affections, } \\
\text { leprosy, hydrophobia, dropsy, epilepsy } \\
\text { and mania. }\end{array}$ \\
\hline \multirow[t]{4}{*}{44} & Ranunculaceae & $\begin{array}{l}\text { Aconitum } \\
\text { chasmanthum }\end{array}$ & Mohree & Herb & $\begin{array}{l}\text { Roots used to treat fever and pain in } \\
\text { body, in piles, gulqand made from } \\
\text { flowers used in different diseases. }\end{array}$ \\
\hline & & Anemone neelamiana & Neeli jari & Herb & $\begin{array}{l}\text { Roots and leaves used in toothache } \\
\text { and measles. }\end{array}$ \\
\hline & & Caltha palustris L. & Kalari patra & Herb & Leaves very bitter, used as febrifuge. \\
\hline & & $\begin{array}{l}\text { Aconitum } \\
\text { heterophyllum }\end{array}$ & Patrees & Herb & $\begin{array}{l}\text { Roots used as tonic, in diarrhea, cough } \\
\text { and vomiting in children. Roots useful } \\
\text { against bites of snake and scorpions. }\end{array}$ \\
\hline \multirow[t]{3}{*}{45} & Rosaceae & $\begin{array}{l}\text { Potentilla eriocarpa } \\
\text { Wall ex Linn. }\end{array}$ & Malli chaw & Herb & $\begin{array}{l}\text { Roots used as tea, paste made from } \\
\text { roots is used to cure toothache, } \\
\text { carminative. }\end{array}$ \\
\hline & & $\begin{array}{l}\text { Rubus fruticosus } \\
\text { Smith }\end{array}$ & Grachha & Shrub & $\begin{array}{l}\text { Leaf extract used in diarrhea. Root } \\
\text { decoction used in cough and sore } \\
\text { throat. }\end{array}$ \\
\hline & & Rosa macrophylla $\mathrm{L}$. & Shingari & Shrub & Fruit edible. \\
\hline 46 & Rhamnaceae & $\begin{array}{l}\text { Zizyphus nummularia } \\
\text { W. Arn. }\end{array}$ & Ber & Tree & $\begin{array}{l}\text { The plant is used live and dead in field } \\
\text { and hut fencing due to its straight stout } \\
\text { and hooked spines. Branches lopped as }\end{array}$ \\
\hline
\end{tabular}




\begin{tabular}{|c|c|c|c|c|c|}
\hline & & & & & $\begin{array}{l}\text { fodder for goats (Capra hircus). The } \\
\text { fruit is sweet, sour; wholesome, } \\
\text { appetizer and stomachic. The leaves } \\
\text { are used for the treatment of scabies } \\
\text { and boils. Decoction of leaves used in } \\
\text { washing of Muslim dead bodies. }\end{array}$ \\
\hline 47 & Rutaceae & Skimmia laureola & Kner & Herb & Used as incense and fumigant. \\
\hline 48 & Scrophulariaceae & Verbascum thapsus L. & Gadhi kan & Herb & $\begin{array}{l}\text { Crushed leaves are used in } \\
\text { rheumatism, mature leaves smoke } \\
\text { against asthma and sore throat, used } \\
\text { against snake bite. }\end{array}$ \\
\hline \multirow[t]{3}{*}{49} & Solanaceae & Solanum nigrum L. & Kach mach & Herb & $\begin{array}{l}\text { The juice of whole plant is used } \\
\text { against ulcers, fever, asthma and sore } \\
\text { throat of babies, fruit edible. }\end{array}$ \\
\hline & & Datura metel L. & Dhaturo & Herb & $\begin{array}{l}\text { Extract of leaves is helpful in } \\
\text { toothache, headache and epilepsy. } \\
\text { Leaves extract effect the nervous } \\
\text { system, overdose may induce } \\
\text { vomiting, coma and even death. Seeds } \\
\text { are antipyretic anti-rabies and narcotic. }\end{array}$ \\
\hline & & Withania somnifera L. & Koori Chinothi & Herb & $\begin{array}{l}\text { The leaves are applied to tumors and } \\
\text { to tuberculosis glands. The roots are } \\
\text { useful in rheumatism, dyspepsia and } \\
\text { lumbago. }\end{array}$ \\
\hline \multirow[t]{2}{*}{50} & Salvadoraceae & $\begin{array}{l}\text { Salvadora oleoides } \\
\text { Dcne. }\end{array}$ & Khabbar & Tree & $\begin{array}{l}\text { The plant is adapted to xeric } \\
\text { conditions and is used for hut fencing. } \\
\text { The fruit has sharp pungent, acrid and } \\
\text { sweet sour taste with a flavor; } \\
\text { appetizer, laxative, carminative, useful } \\
\text { in piles, tumors, bronchitis, } \\
\text { biliousness, ascites. The root bark is } \\
\text { used as a vesicant. The leaves are used } \\
\text { as an antitussive and as a purgative. } \\
\text { Fodder for camels (Camelus } \\
\text { dromedarius). }\end{array}$ \\
\hline & & Salvadora persica $\mathrm{L}$. & Khabbar & Tree & $\begin{array}{l}\text { The fruit is deobstruent, carminative } \\
\text { and diuretic. Bark of the root is } \\
\text { vesicant. The shoots and leaves are } \\
\text { pungent and are used as an antidote to } \\
\text { poisons of all sorts. Fodder for camels } \\
\text { (Camelus dromedarius). The juice of } \\
\text { the leaves is given in scurvy. The } \\
\text { natives use root as toothbrush as it } \\
\text { strengthens the gums, keeps them from } \\
\text { becoming spongy, and improves } \\
\text { digestion. }\end{array}$ \\
\hline \multirow[t]{3}{*}{51} & Tiliaceae & $\begin{array}{l}\text { Corchorus depressus } \\
\text { (L.) Stocks }\end{array}$ & Mundhiri & Herb & $\begin{array}{l}\text { The plant is sweetish hot sharp acrid; } \\
\text { removes tumors and pain; cures piles. } \\
\text { It is given as a cooling medicine in } \\
\text { fevers. The leaves are emollient. The } \\
\text { seeds in decoction with milk and sugar } \\
\text { are given as a tonic. }\end{array}$ \\
\hline & & $\begin{array}{l}\text { Tamaracaceae } \\
\text { Tamarix aphylla } \mathrm{L} .\end{array}$ & Lai & Tree & $\begin{array}{l}\text { Branches used locally for basket } \\
\text { making or partition screens. Galls } \\
\text { obtained from the tree are used as an } \\
\text { astringent and as a dye. The wood is } \\
\text { used in turnery, for making } \\
\text { agricultural implements } \\
\text { (ploughs/yokes). The bark is bitter, } \\
\text { astringent and aphrodisiac it is also } \\
\text { used in treating eczema and capititis. }\end{array}$ \\
\hline & & Tamarix indica Willd. & Lai & Tree & $\begin{array}{l}\text { The bark is bitter and an astringent, } \\
\text { tonic. Fruit and leaves are useful for } \\
\text { dysentery and chronic diarrhea. The } \\
\text { wood is of the greatest utility as fuel }\end{array}$ \\
\hline
\end{tabular}


Ethnobotanical Importance of Some Highly Medicinal plants of District Muzaffarabad.

\begin{tabular}{|c|c|c|c|c|c|}
\hline & & & & & $\begin{array}{l}\text { by the natives. Branches are used for } \\
\text { basket making. Bark is astringent and } \\
\text { tonic. }\end{array}$ \\
\hline \multirow[t]{2}{*}{52} & Umbellifereae & Angelica glauca $\mathrm{E}$. & Chora & Herb & $\begin{array}{l}\text { Dried roots and seeds are used as } \\
\text { spices and condiments. Root extract } \\
\text { used in different cattle diseases. Useful } \\
\text { in dyspepsia and constipation. }\end{array}$ \\
\hline & & Bunium persicum & Kalazera & Herb & $\begin{array}{l}\text { Used as spice in curries, carminative } \\
\text { and useful in headache. }\end{array}$ \\
\hline 53 & Urticaceae & Urtica dioica $\mathrm{L}$. & Kairi & Herb & $\begin{array}{l}\text { Root extracts used in easy delivery in } \\
\text { females. Causes irritation when } \\
\text { touched. Decoction of leaves is useful } \\
\text { in rheumatic pain, while paste of } \\
\text { peeled leaves and twinges applied } \\
\text { externally for skin diseases. }\end{array}$ \\
\hline \multirow[t]{2}{*}{54} & Verbenaceae & $\begin{array}{l}\text { Clerodendrum } \\
\text { phlomoides L.f. }\end{array}$ & Gharayat & Shrub & $\begin{array}{l}\text { The root is used as a bitter tonic and is } \\
\text { given in the convalescence of measles. } \\
\text { The juice of the leaves is useful in } \\
\text { syphilis. }\end{array}$ \\
\hline & & Phyla nodiflora $\mathrm{L}$. & Bukan & Shrub & $\begin{array}{l}\text { The plant is hot and dry; diuretic, } \\
\text { useful in fevers and colds. A poultice } \\
\text { of fresh plant is maturant for boils. } \\
\text { Infusion of tender stalks and leaves is } \\
\text { useful to children suffering form } \\
\text { indigestion and to women after } \\
\text { parturition. Chutney made from the } \\
\text { leaves and fruit is eaten to relieve the } \\
\text { irritation of internal piles. It is fodder } \\
\text { for goats (Capra hircus) and sheep } \\
\text { (Ovis aries). }\end{array}$ \\
\hline 55 & Vahliaceae & Valeriana jatamansi & Mushk-bala & Herb & $\begin{array}{l}\text { Stimulant tonic and useful in cough, } \\
\text { epilepsy and neurosis. }\end{array}$ \\
\hline 56 & Violaceae & Viola biflora Wall & Banafsha & Herb & $\begin{array}{l}\text { Leaves are laxative, roots emetic, tea } \\
\text { made from roots and leaves used to } \\
\text { treat fever. }\end{array}$ \\
\hline 57 & Zingiberaceae & Zizphus vulgaris & Unab & Herb & $\begin{array}{l}\text { Seeds edible and useful in pectoral and } \\
\text { lung diseases. }\end{array}$ \\
\hline \multirow[t]{3}{*}{58} & Zygophyllaceae & Fagonia bruguieri DC & Drummahu & Tree & $\begin{array}{l}\text { Whole plant is acrid and bitter cooling } \\
\text { useful in asthma, fever, thirst, } \\
\text { vomiting; cures dysentery, ophthalmia, } \\
\text { toothache, stomatitis, leucoderma, } \\
\text { biliousness and snakebite. }\end{array}$ \\
\hline & & Peganum harmala $\mathrm{L}$. & Hurmal & Herb & $\begin{array}{l}\text { The seeds contain the alkaloids } \\
\text { Harmalin, Harmalol and Harmine; the } \\
\text { seeds are antispasmodic, narcotic, } \\
\text { hypnotic, anodyne, emetic, } \\
\text { emmenogogue, stimulant, alternative, } \\
\text { aphrodisiac, lactogogue, anthelmintic } \\
\text { and abortifacient; they are also used in } \\
\text { remittent and intermittent fevers, } \\
\text { colics, retention of urine, cough and } \\
\text { other pectoral disorders. A decoction } \\
\text { of crushed seeds is also useful in } \\
\text { mouthwash in laryngitis. The seeds } \\
\text { yield a dye, which tribals use for } \\
\text { dyeing the hair of sheep (Ovis aries) } \\
\text { and goats (Capra hircus) as an } \\
\text { identification mark. }\end{array}$ \\
\hline & & Tribulus terrestris L. & Bhurt & Herb & $\begin{array}{l}\text { The leaves are used as gargle for } \\
\text { stomatitis. The fruits are cooling, } \\
\text { diuretic, tonic and aphrodisiac. Also } \\
\text { used in painful maturation, calculous } \\
\text { affections, urinary disorders and } \\
\text { impotence. Tribals eat the fruit as food } \\
\text { especially in times of famine. }\end{array}$ \\
\hline
\end{tabular}




\begin{tabular}{|l|l|l|l|l|}
\hline & $\begin{array}{l}\text { Zygophyllum simplex } \\
\text { L. }\end{array}$ & Alethi & Herb & $\begin{array}{l}\text { The seeds are anthelmintic; swept up } \\
\text { off the ground and eaten by the poor as } \\
\text { food. It is camel's heartiest fodder. An } \\
\text { infusion of leaves is useful in } \\
\text { ophthalmia and leucoma. }\end{array}$ \\
\hline
\end{tabular}

The use of plants is indicative of intimate and relationship of the people of hilly areas with the vegetation in their vicinity. However, there is an ample traditional knowledge of medicinal plants, which need to be fully documented for the restoration of disappearing knowledge as cultural heritage can be used as a source of new medicine.

\section{Acknowledgements}

The authors are grateful to M. Iqbal Dar, the Herbarium incharge, QAU and Director NARC herbarium, Islamabad for the opportunity to study all herbarium collection and literature survey. We are also thankful to Mr. Shafique and Mr. Altaf of the Botany Department of Azad Jammu and Kashmir University for their cooperation for the completion of this study.

\section{References}

[1] R. E. Schultes, Trapping our heritage of Ethnobotanical tour, Econ. Bot., 14, 1960, 257-262.

[2] R. E. Schultes, The role of Ethnobotany in search of new medicinal plants, Lioydia, 25, 1962, 257-266.

[3] S. R. Altschul, Psychopharmacological notes in Harvard University Herbarium, Lioydia, 30(2), 1967, $192-196$.

[4] S. R. Altschul, Unusual Food plants in Harvard records, Econ. Bot., 22(3), 1968, 293-296.

[5] S. R. Altschul, Ethnogynaecological notes in Harvard University Herbaria, Botanical Museum leaflets Harvard University, Cambridge, Massachusetts, 22(10), 1970, 333-343.

[6] S. R. Altschul, Drugs and foods from local known plants, (Harvard University Press, Cambridge, 1975).

[7] S. R. Altschul, Exploring the Herbarium, Scientific American, 1977, 96-104.

[8] J. E. M. Arnold and R. M. PEREZ, Can non-timber forest products match tropical forest conservation and development objectives, Ecological Economics, 39, 2001, 437-447.

[9] O. L. Phillips and B. A. Meilleur, Usefulness and Economic Potential of the Rare Plants of the United States, A Statistical Survey, Economic Botany, 52(1), 1998, 57-67.

[10] H. Ojha, P. Bhattacharya and J. Bharati, Fulfilling Societal Needs through participatory Silviculture an Evaluation, Proceedings XXI IUFRO World Forestry Conference, Vol. I, August 7-12, 2000, Kuala Lumpur, Malaysia.

[11] T. Ticktin and T. Johns, Chinanteco management of Aechmea magdalenae (Bromeliaceae) implications for incorporating TEK and TRM in management plans, Economic Botany, 56, 2002, 43-57.

[12] M. H. G. Gustafsson, V. Britich and P. F. Stevens, Phylogeny of Clusiaceae based on rbcL sequences, International J. of Plant Science, 163, 2002, 1045-1054.

[13] C. P. Kala, Indigenous knowledge of Bhotiya tribal community on wool dying and its present status in the Garhwal Himalaya, India, Current Science, 83, 2002, 814-817.

[14] M. L. Leporatti and E. Lattanzi, Traditional Phytotherapy on coastal area of Makran (Southern Pakistan), Fitoterapia, 65(2), 1994, $157-161$.

[15] S. M. Goodman and A. Ghafoor, The Ethnobotany of Southern Balochistan, Pakistan Fieldiana, Bot., 1, $1992,1-84$.

[16] J. W. Harshberger, Purposes of ethnobotany. Botanical Gazette, 21, 1896,146 -154.

[17] A. U. Khan, History of Decline and present status of natural tropical Thorn forest in Punjab, Biological Conservation, 67(3), 1994, 205-210.

[18] S. Hijazi, A Phytosociological study of Margala Hills National Park, Islamabad, M. Phil. Thesis, Quid-i-Azam University, Islamabad, Pakistan, 1984.

[19] K. F. Akbar, Phytosociological Studies of the Quid-e-Azam University Campus, Islamabad, M. Phil. Thesis, Department of Biological Sciences, 1988.

[20] H. G. Champion, S. K. Seth and G. M. Khattak, Forest Type sof Pakistan, Pakistan Forest Institute, Peshawar, 1965.

[21] G. M. Hocking, Pakistan Medicinal Plants I, Qualitas Plantarun Et Material Vegetables, 5, 1958, $145-153$.

[22] G. M. Hocking, Pakistan Medicinal Plants IV, Qualitas Plantarun Et Material Vegetables, 9, 1962, 145-153.

[23] M. I. Shinwari and M. A. Khan, Folk Use of Medicinal herbs of Margalla Hills National Park Islamabad, J. Ethn., 69, 1989, 45-56.

[24] K. R. Shehzad and R. A. Qureshi, Common Ethnobotanical Uses of Plants in Jatlan area, District Mirpur (A. J. K.). Hamdard Medicus, 3, 2001, 42-45.

[25] Z. K. Shinwari, The Ethnobotany in Pakistan., Proceeding of $1^{\text {st }}$ Training Workshop on Ethno botany and its Application to conservation, NARC, Islamabad, 1996, pp. 14-25.

[26] S. A. Hamid, W. Sabir, M. Salim and T. A. Choudry, Medicinal Plants of Family Cannabaceae, Humdard J. Sci. and Medicines, XLI, 1998, 111-112.

[27] E. Nasir and S. I. Ali, Flora of Pakistan, Pakistan Agricultural Research Council, Islamabad, Deppt. Botany, Univ. Karachi Pakistan. Eds. 1970-1987, 1-187. 